事業墨は長期器画の約 $14.5 \%$ にすきないここに主要 地方道虏除いた一般府県道以下の比較的下級の道路の
新設, 改築の長期計画に対する比率は $7.9 \%$ にすきず, これらの全般の改良は容易でないことがわかる。

\title{
Relation between the Rate of Fuel Consumption and Road, Conditions
}

\author{
by Shozo Tanifuji
}

(Public Works Research Institute Ministry of Construction,)

SYNOPSIS:- The author described Japanese motor car transportation, roads and the present states of paving roads in ontline, and results of investigation of roads in use of the test car by Public Works Research Institute in detail. Especially, relations be tween the rate of fuel consumption and the kind of road surface, speed, gradient and fuel economy in case of pavements and so on were described.

U.D.C. $656.7(52)$

\section{わが国民間航空の現状こその將来}

（昭和 30 年 3 月 8 日例会講演会講演）

\section{運輸省航空局 大 沢信一}

要旨：わが国の民間航空々多年の空白時代を経て再発足して以来わずかに 3 年しかたつてい ないので諸外国に比して著しく和くれている。今後朝蘚, 台湾をねじめ東南アジア, 中共地域 との交通が頻繁になるととが予想され，わが国の民間航空も一段と重要性を㴰すものと思われ る。從つて現在民間航空が直面している数々の間題を解決して 1 日も早く世界の水準にまで持 つてゆかねばならない。

\section{I.むえがき}

わが国の民間航空は，御咸知のごとく多年にわたる 空白時代を経て再発足後漸く 3 年しかたつていないの で，諸外国のそれに較へれば遥かに立ちおくれてい る。すなわち昭和 25 年末にいたり, 国内航空運送事業 令が出て, 運輸大臣の免許を受けて国内の航空運送事 業を営も途が開かれたのである。と申しても，依然と して日本人はいかなる航空機も所有することはもちろ ん，操縦することも整備することすら禁止されたまま の状態であつたので，外国機のテャーがーによるきわ めて変則的な運送事業であり，天下晴れて自主的な民 間航空が始まつたのは平和條約が発効した炤和27年の 春, 厳密にい光ば航空法が施行せられた同年 7 月から である。それも何一つない新規蒔き直しの状態でスタ ートしたわけである。残つていたものといえばかつ ては相当やつたものだという経験位なもので，それも 7 年の歳月を経てはすでに陳腐なものとなつていたの
である。加うるに経済面，国際面若しくは技術面の凡 ゆる悪條件が堆積していたのでテンャワンャの迂余 曲折を経て，それでも今日では日本の国籍を持つ航空 機が合計 238 機に上り，その内訳は飛行機 108 (単発 79, 双発 12, 四発 17), 回転翼航空機 21, 滑空機 109 となつている。国際的にも昭和 28 年英国ブライトンに おおる I.C.A.O. 総会においてシカゴ㣠約への加大を 認められ，世界の航空界の仲間大りをしたわけである。 ここにシカゴ條約とは国際民間航空條約と称せられる ものであつて，国際民間航空が安全に，かつ整然と発 達するように，また国際航空運送事業が，機会均等主 義に基いて確立され，健全かつ経済的に運営されるた めに，各国が協力しようという取極めであり，I.C.A. O. というのはその事務局である。かかる條約は昔か らあり，わが国はパリ條約というものの加盟国であつ

\footnotetext{
* International Civil Aviation Organization
} 
た。これは主として欧洲おょびアジアの諸国が集つて できた條約でありこれとは別に米大陸づループには ハバヲ條約があつたが，第 2 次大戦の経験により，航 空はこのように世界虍 2 分していたのでは十分にその 機能を発揮できないということになつて打つて一丸と したシカゴ條約に発展したものと思われる。この條約 ができたのは1944年であつて，わが国はまだ戦争状態 にあつたのでとり残されていたわけで，交化国家の一 員としてことに外国製の航空機を購大し，さらに国際 進出をするためにはまず必要な抢つき合いである。き カゴ條約には各種の附属書があつて航空機, 航空彷事 者, 航空路㧍よび附属業務に関する規則, 標準, 手続 および組織に関する国際的な水準を規定しておる。加 盟国はこの国家水準と同等若しくはとれ以上の国家基 準を定的て実行する義務祀負い，従つて加盟国相互間 では互いに相手の国家基準を信用し尊重し合抢うとす るもので，現在加盟国は約70カ国に達しており，少く ともこの加盟国内に関する限り国境という観念なしに 空の自由が満契できるわけである。話が少しわき途に それたが，とに角色々な難問題にぶつかりながら，一 方このように着々と国際的な態勢もととの元て今日に 至つたわけである。その現状を個々について述へるこ ととする。

\section{II. 日本航空}

1）国内線 前に国内航空運送事業令に基き航空輸 送が始つたと述べたが，まずこの仕事を開始したのが 日本航空株式会社である。N.W.A.*とのテャーター契 約により北海道から九州に至る本州縦断幹線の定期航 空を始めたのである。 N.W.A. の持つてきたマーチ ン 2-0-2 という双発 40 人乗の新鋭機を便用し，一応 順調に滑り出したのであるが，昭和27年の春，三原山 の不幸な事故が発生して，その後半年余りは旅客がタ 落ちといううき目にあつた。昭和27年10月から始めて 航空法に基く自主的な定期航空運送事業に移つたので あるが，使用機はダグラス DC-4であつた。前述マー チンより旧い飛行機ではあるが, 戦前同しくくダグラス DC-2, DC-3 そ数多く使用した吾々には，殊に信頼 感が強く, 事実全世界に広く使われているよい旅客機 である。現在 DC-4 7 機を所有し，千歳，伊丹お上 び板付間を運航しており，季節その他により多少の増 減があるが，大体毎日各線 3 往復の運航を実施でき る。それらの航空機の整㣁は姉妹会社である日本航空

\footnotetext{
* Northwest Airlines

** Pan American World Airways

*** Canadian Pacific Airlines.
}

整備株式会社に行わせているが，元来あちらこちらか ら寄せ集めた機体であるため同じ DC-4 とはいうもの の細部の艤装においては全く不統一であり，整䚛作業 や部品の補給にも一方なら苦学があつたので, 昨年 春から順次各機の根本的なオーバーホールおよび大改 造觉行つて概叔完了し面目を一新した。運航率は大体 95\%を維持し，旅客の利用率も $80 \%$ 前後を確保してい て世界の一般水淮を逵駕し，旅客拈よび貨物の輸送量 は漸增している。

2) 国際線 国際航空は各国航空会社がいずれも自 国政府の積極的な保護の下に，相互に激烈な競争を行 つているので，わが国の航空会社がこれら先輩諸会社 との競争に耐元て国際航空界に進出寸るには，各国の 実例に徴しても明らかなごとく，強力な経営基礎を有 する会社をしてこれに当らしめ，政府がこれに対して 積極的な妄成措置を講ずる必要が痛感されたので，昭 和28年日本航空株式会社法が制定施行せられこれに 基いて同10月1日から日本航空株式会社が設立せられ たのである。従つて名称は同じであるが，この時から 旧日本航空の榷利義務をそのまま承継して国内幹線上 の航空運送を営む外，国際進出を使命とする新日航か 生れたわけである。まず考元られた国際路線は東京一 サンフランシスコであるが, 当時太平洋横断路線を有 する航空会社としては南廻りとして米国のP.A.A., 北 趈りとして同しく米国の N.W.A. およびカラダのC. P.A.L. がありそそれぞれストラトクルーザー，ダグ ラス，ロッキード等の優秀機を使用して実積を固めて いたので，まず使用機の決定が大問題であつだ。米国 ダグラスおよびロッキードの 2 大航空機メーカーから 盛な売込があり，おのおの一長一短があつて去就に迷 う有様であつたが，すでに国内線用として DC-4 を使 つているという事実は，同系統の機種の方が何かにつ け共通な点が多からうということと, 大手條件が有利 な方というわけで，ダグラス DC-6B に決つたので ある。全備約 $50 t$ ，今日においては世界最優秀機であ るが, 競争激甚な国際航空界においては数年ならずし て時代遅れとなる可能性があるので, 将来に備えてイ ギリスが世界に誇るデ・スビランドコメッ下在2 機子 約発注したのである。かかる第 1 線級の旅客機になる そ，乙の採用入手については各ェアラインとも非常に 研究し苦労しているが，それはメーカーに発注して大 手までに早くて 2 年はかかるという事赛である。従つ てダグラスなりロッキードなりに注交して求める新造 機より中古機の方が遥かに高価である。余訫な金を払 うのが㵒ならいわゆる先物買なして，まだ設計中の航 
空機を予約注文し， 2 年なり 3 年なり待だはばならな いのである。各航空会社が海のものとも山のもの方も つか好ターボプロプ機やジェッ下輸送機を注交して, 一日でも早く最新鋭機の獲得に狂奔するのは，これを おいて競争の武器がないからである。I.A.T.A. とい うエアラインの国際的な組合があって，運賃は申寸に およばず，客席の閒隔から提供する機内食の金額まで 協定しているから，あとは安全確実な運航と豪華快速 な使用機で競争する以外手がないのである。勿論日航 もそのメンバーであつて，協定から冕脱することは許 されない。よくステュワーデスのサービス云々がいわ れるが，それ程效果があるとも思われず，又昔わが海 軍華かなりし頃，外人が好んで日本船を利用したのは その食事が優れていたためといわれるが，数時間ない 乙数十時間の旅ではこれも大した問題でなくなってい る。このようにして胙年 2 月 2 日から東京一サンフラ ンシスコ間，同じく 5 日から宋京一沖繩間の定期運送 を開始ここにはじめてわが国は待望の国際線進出を 実現，本年 2 月 4 日からは東京一沖繩線を香港まで延 長した。現在 DC-6B 5 機を以てサンフランシスコと の間に週 3 往復, 香港 2 往復の運航を行つている。 新米の日航が国際競争場裡に乘出して如何程の業樍を 挙げ得るかは何人も予断ができず，悲観的な見方が多 かつたのであるが，蓋をあけてみると案に相違して仲 々利用者が多くことに昨年 4 月からッーリスト・サ ービス実施以来就航率は 95 100\%，旅客の利用率も 50〜60\%という意外の好成績をあげている。ただ国際 線については当分の間，機長は外人に依存せざるを得 ずまたその整供については，サンフランシスコの U.A.L. に頼んでやつて鿓うという余り威張れない現 状にある。目下, 日航整備が羽田で実施できるように 施設の準備をすすめる傍ら，随時技術者を米国に派遣 して技術習得に努めているが，機長の問題は早急には 解決が望み得ない事情にある。すなわち日本人操緃士 の中からその資格のある者を得るまでになお時日を要 することと，相当数の外人旅客を吸収している実情か ら, パイロットに対する外人の信頼感といつた問題も あるようである。

3）日航の経営状況 すでに述べたごとく，国際路 線については強力な国家のバックを要するために，現 在日航に対しては20億の政府出資を行つている。その 他に民間資本13億, 合計 33 億の資本金であるが，国

* International Air Transport Association ** United Air Lines
際・国内を通じて決して悪いとはいえない営業状態に ありながら，昨年 9 .月期の決算において合計 8 億の赤 字を出している。これは航空機の購大, 国際線の開設 準備などに多額の資金を要したため，全体として収支 相償うところまで至つていないのであつて，これまで 買入れた DC-4 7 機，DC-6B 5 機, ビーチクラフ 下 2 機, ブ・ハビランド・ヘロン 3 機のための所要資 金だけで約80億に上つており，整䜤施設および訓練費 などの資本的艾出を加元ると約 100 億円の固定資本を 投下しているし，その総経費を調へると，運航費すな わち航空機材消却費, 航空機整備費, 燃料費, 乘員費 なとが約 8 割を占めているので，経営合理化によるコ ス下引下げの余地はきわめて少いものと思われる。外 国航空会社の例をみると営業費その他心わ的る運航費 以外の経費が総経費の 5 割程度を占めているのが通例 であつて，日航の場合すでに 2 割にまで圧縮している のであるからこの面での節約は多くを期待できず，乙 からば運航費えのものが高いかというに，成程新たに 購大した機材ばかりでその償却費が大きく現われてい るのは当然ながら，安全運航を第一義とする旅客輸送 であるから，整㣁費等を無下に切下げることは危険で ある。うすれは運賃が安過ぎるかということである が，国際線は前述のごとく各社共通で論議の余地な く，国内線については哩当り4〜4.5セントで諸外国の 例と較へ，ほほ中庸を行つているのであつて，乙れを もう少し引上げることも一忩は考えられるが，現在の 航空運貨は各路線とも国鉄 1 等運賃を上廻つて动り， 急行 2 等寝台に輘へると, 東京一大阪で 5 割高, 東京 一博多間では片道 5,000 円高の約倍額になつている。 国民の所得も鉄道の運賃も低いかが国では，コストが 外国なみあるいはとれ以上かかるにも物らす航空運顀 を可上げることは，かえつて利用率低下によるマイナ スの方が大きくなるのではないかと思われる。これを 解決する唯一の名案として, 通行税の廃止が最も妥当 であるといわれている。現行通行税は 2 割であるが， この金は航空運賃に含めて旅客が負担し，しかも何等 会社の収入にならないのである。わが国の通行税が鉄 道は $1 ， 2$ 等, 海運は 1 等旅客にのみ課せられている ことなるれば，高額な航空運貢を支払い得る者には担 税能力ありとして一種のしやし税的な意味で課せられ ると思われるが，現代の航空機は旅行時間の節約とい う特殊な効果を有するからこそ利用され，旅客はその ために高額な運貫を支払うのであつて，この点旅行 時間の等しいのにかかわらず単に安楽を求めて高額運 梖を支払う船や鉄道の優等旅客とは根本的に異るので 
ある。恰も郵便利用者之電報利用者を比較し，後者に 担税力ありとして課税するに等しく，皮相的な見解に すぎなとい兄よう。要するに航空事業を育てて行く ために旅客の負担を増大することなしにその収入を はかるには，この通行税の廃止か唯一の手段てあると して航空局ても强力に推進しているわけである。若し これが実現すると日航の場合年額約 4 傹円の増収とな り，少くとも国内線については黒字となるはずてあ る。

\section{III その他の定期航空運送事業}

日航が国内幹線を運航している外，ローカル定斯航 空重業原行うものとして, 日本ヘリコプター輸送株式 会社と極東航空株式会社の 2 社がある。前者は東京一 三冯一千藏打上ひ東京一名古屋一大阪の雨路線を, 後 者は大阪一岩国一福岡の路線について，それそれ定期 航空運送事業觉行うとともに，さらに両者とも東京一 大阪間の夜間郵便専用定期航空をも運嫦している。日 本へリコプターは日航からテャーターした4発14人乘 のデハビランド・ヘロン 3 機と双発ダブ 2 機を，極東 航空はこれも英国製の 4 発22人乘ハンドレページ・マ ランソ 2 機とダブ 2 機を使つている。日航に較へれば 小さな会社てあり，全くの私企業として経営している が旅客利用率は $50 \%$ 内外という余り芳ばしからざる実 績てあるが，一般国民の認識も薄い上に，ローカル定 期とはいいなからら日航と同一航路上をほとんと同一の 運貨て飛んでいるのて，偶々中間着陸地へ行く旅客以 外は矢張り同しことなら大型機てという人間の心理も 現われているものと思われる。経宮状態は何れも赤字 を続けているが，その事情は日航の場合とほとんと同 して, 航空運送事業の性質上, 開設当初加黒学定期 待する方が無理なのかも知れない。

\section{IV. 不定期航空運䢝事業と航空機使用事業}

日航，日パリ打よひ極東 3 社のほか10社かえれそれ 不定期航空運送事業の免許危得て運営している。航空 機使用事業になると，以上の各社を含めて合部 23 社が 免許を受けており, 宣伝広告, 空中写真測量, 㑭群発 見, 農菜散布なとあらめる知慧を絞つて広範国な分野 で活躍しているが，何しろ狭いわか国の需要に対して 余りにも事業者の数が多く，一眭ビラ播きとの他航空 機を使用する宣伝広告が珍らしがられてかなりの成績 をあげたこともあつたが, デフレ傾向と相まつてその 経営は非常に苦しい模栐てあり，中には航空機の所有 権が他人の手に渡つてしまっているものもある現状て ある。元来航空機使用事業の採算分岐点は 1 日当りの 有償飛行時間約 1 時間半程度といわれているが，実績
の示すところては40分ないし50分に過きず明らかに供 給過剩の様相を呈している。何か故にかく多数の使用 事業觉認めたかという点をよく尋礼られるが，法律に よると，定期，不定期事業と同しく免許制にはなって いるものの, 国民の福利を目的とし, かつ航空保安上 支障かないと認めれば運輸大臣は認可することになつ てちり，需給のバランスはその條件になつていないの てある。法律を作るときから論議されたことていあつ たが，アメリカなとの例をみれは使用事業は単に届出 制をとつていて，好きて始めて動きがつかなくなつて 廃めるの!自由にさせておく方がよいのかも知れな い。たた経㗬か苦しくなつて経費節約の要に迫られて のシワ寄せが整備関係におよひはしないか。つまり整 備要員与减らしあるいは当然交換すへき部品をもう軗 くそのまま便うということがあつては由々しき大事て あり，一番目につき難い点だけに警戒をしている。

\section{$\nabla$ ．自家用機とヘリコブター}

アメリカあたりてはオーテードライブというか，自 家用機を持って一寸飛行したり，スポーツとして楽し む人も少くないのてあるがわが国てはまだそこまで に至つていない。自家用機といつても新聞社その他の 社用機が大部分である。平和條約発効の翌日から飛行 機を持つて飛ほうと集備したのがこの新聞関係てあつ て，主として宣伝効果学衫らつたものてある。朝日， 毎日, 読売, 産経抢よひ中日の 5 大新聞社であるが, お互いに製制しつつまた引張られて2機になり 3 機に なり,ヘリコプターを持ち, 双発機を手に入れるとい つた状態てある。戦前, 新聞社の航空機といえば通信 報道のための一大威力て随分力も大れたものてあつた が、テレタイプがてき, 電送写真の発達した現在ては すでに当時の様な鬽力を失つている。おまけに機材購 入坅よひ維持に少なから好経費を要するのて，まあ一 種の道楽息子を持つた気ているようてある。従つて最 初は世いせい単発の軽飛行機てとまりかと思われた が，明神礁の爆発があてとうしても双発が要るとい うことになつたし，今回のことく総選挙でもあると， 自社の航空機を総動員するのはもち万ん国内にある航 空機という航空機は1 機残らずいずれかの新聞社にテ ヤーターされて号外運ひに先陣を争うのてあつて, 嫝 応なしに徐々に大型化し，穖数もふえて行くのてはな いかと思う。

ヘリコプターは戦後始めて輸大されたものてある が,日本の地理的條件に適していると思われたことと， もう一つは日本人特有の新しがりやからわれもわれも とへリコプヌー熱にうかされたのてある。ところが1 
1 機头りの瞒入亚格に飛行機に較へると非常に高い上 に，事故が続出してこのところ一括さよつ形であ る。これはへッコプターというものの考光は相当古く から，西り，多年の研究の結果やつと実用化したもので あるだけに，先の洒格には莫大な研究費の償却が見込 まれているのてありまた非常にデリケートなものて あるたけに整い気持て十分哪れない者が操縦すると事 故が起きるのてある。

\section{VI.かが国に乘入れている外国航空会栭}

現在まてに正式に許可を受けてわが国に乘大れてい る外国航空会社としては, 米国から N W.A., P.A.A. の 2 社, 英国から B O.A C., 㡺洲から Q E A., タイ から T.A.C， カォダから C P A L , 中国からは C. A.T), オランダから K.L M), 北欧三国加 S.A.S., フランスから A F. と都合10社の多きに達している。 これらの会社機が实から西から，北から南から，それ それ週1往復ない乙4往復, 思心思心の路線を東京を目 かけ昇んでさている。この中 Q.EA.とCA.T.だ けが岩国に奇るが，すへて東京羽田空巷に集中するの で羽田は正に極東にらける空の要点となつている。機 種はカーテスコマンド，各がラス DC-3, DC-4, DC6. DC-6B，ボーイングストラトクルーザー，口キ ードコンステレーション, 同しくスーパーコンステレ ーションにコメ，下と多士畜々であって，29年中の国 際線使用機の羽田空港に枋ける離発着回数だけで月平 均約 500 回, 国内線を加光ると 1,600 回に抢よび，こ の他にこれとほほ同数若しくはとれ以上の米軍機が上 り降りじているので，1日平均実に100回以上であ り, 日本の空の去関となつた羽田空巽の繁栄振りが想 像されよう。

\section{VII. 諸外国との航空双務協定の繯結状況}

昭和 27 年 8 月米国々の間で民間航空運送協定に調印 して以来今日までに英, 蘭, スウェーデン, デンマー

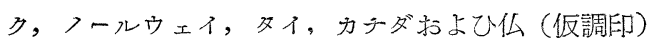
の諸国とすてに航空双務協定卆締結している。現在交 渉中のものに，ブラジル，ベルギー，中華民国，イン ド，パキスヌン，ビルマ、イヌリーなとがある。

\section{哑. 飛行 場}

以上述べたところにより国際抢よび国内の民間航空 の現状をほほほ分つていただけたかと思うが，いかに航 空機を扮元事業厄始めたところで民間航空ことに国内 航空は発達するものでい。民間航空の一環として忘 れてはならない重大な要素が幾つかあるのである。そ の第一が飛行場である。わが国には現在約90の飛行場 があつて，その中50の飛行場は在日米軍に提供されて
いる。これら提供飛行場は横田，入間川，厚木を除け ば一応民間機の発着を認められ，まに干歳，三沢，仙 台，伊丹，岩国抢よひ板付は定期航空用としての使用 をも承認されている。

その他の飛行場は平和條粎の発效後レリーズされたも のや，在日米軍に接収もされす，また農地なとに開放 もされず, 飛行場として使用可能な状態て存置されて いるものなどで，日本側の管理下にあるのであるが， 航空法に基いて正式な飛行場として設置されたものは 東京国際空港在始めとして, 大府, 藤沢, 読売玉川, 宇都宮, 宮崎, 熊本抢よひ鹿児鼻の 8 飛行場に過さず， 他にへリポートとして, 東京, 仙台, 会侓, 大村, 函 館があるだけである。このような状態であるから幾ら 飛行機を持ってきてもことに小型飛行機にとつて便利 に手軽に使える飛行場が全く足りないのである。東京 空港は申すに及ばず国内定期航空に使用する飛行場は いずれも大型機と米国機の発着にフルに使われている から，これら大都市に近接した中小型機用飛行場の設 置が強く望まれてお方。丘球, 調布, 阪神, 雷根なと がそれてあつて，一日も早く整備されることが民間航 空発達のための重要な課題となつている。な抢東京国 際空港は，わが国唯一のインターナショケル・エアポ ートであつてすでに返還されているのて表面上日本政 府て管理しているが，依然として M.A T.S. の日本 における唯一つのベースであつて，建物地域の大部分 は未だ解放されて抢らず，そのため非常に狭险をきわ めている。外国から到着した人が口を拼えていうこと は，日本の玄関が狭く挶いとこであつた。そこて現在 のターミテルと全く別の場所に新ターミッ゙ルを建設中 で，来る5月には堂々たる新ターミテルルが完成するこ とになつている。このターミナルへは1本の滑走路を 横切つて行かねばならないので，その部分は地下道に なっている。

\section{X. 航空保安施設}

飛行場々並んて近代航空機の航行に不可欠のものは 航空保安施設である。これは電波，灯火なとにより航 空機の航行々援助するための施設て航空保安無楾施設 と航空灯火に大別することができる。
1) British Overseas Corp.
2) Quantas Empire Arrways.
3) Thai Airways Co. Ltd.
4) Civil Air Transport
5) Royal Dutch Air lines.
6) Scandinavian Airlines System
7) Compegnie Nationale Air France
8) Military Air Transport Service 
1）航空保安無線施設 指向性または無指向性の 電波を発射して航行中の航空機に正しいコースや位置 を知らせる施設で, ラジオ・ビーコンとい゙われ，東京， 大島，名古屋，福岡など22力所に配置されている。大 部分は日本側の施設としてその責任と負担において運 用しているが, 立川, 峰山, 小松, 新潟, 厚木, 熊谷 および木更津の 7 カ所はな抢在日米軍の管理下にあっ て，日本側はその委託を受けて運用に当つているに過 ぎない。次に G.C.A. (地上進入管制装置) は干歳, 三沢, 東京, 小牧, 伊丹, 岩国拉よび板付に設置され てよいるが。これは地上のレーダーであつて，着陸し うとする航空機をキャッチしてその方间，高度などを 修正して指示を与克, 計器飛行状態における着陸安可 能ならしめるものであつて，現在はすべて米軍の手で 運用されているので，これらを将来全面的に日本側に おいて運用できるように目下要員を訓練中である。ラ ジオ・レンジ・ビーコンより一段発達したォムニレン ジや，地上から指示するのではなく機上で方向や高度

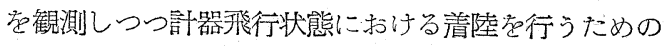
I.L.S.といつた新式の施設は遺憾ながらまだわが国に は設置されて抢らない。

2）航空灯火 航空灯火には色々な種類のものが， あるが，その中で航空灯台は現在31力所ある。国が設 置し，維持運用しているものは26力所であり，他は民 営である。今日のごとく全天候飛行の時代になると霧 や雲でみえなくなる灯台は余り有効でなく，視界が利 く場合には夜閒と雖も海岸線や河川が明膫に識別でき るので,わが国のような地勢においては左程重要でな くなつたともいえるが，安全性増大のためにはある に越したことはなく，ことに飛行場の位置を示す飛行 踼灯台は是非必要であるといわれている。年他飛行 場に設置する滑走路灯，碭周灯など各種の灯火之高い 障害物件を識別するための航空障害灯も相当設置され ているが，まだ十分とはいい難い現況である。

\section{X. 航空通信施設}

航空通信は航空機の運航に是非共なければならない とともに，航空の特色として国際的な標準に基いて運 営されなければならない。航空通信に関する国際法規 として国際電気通信條約, 国際民間航空條約 $x^{\circ}$ あ, 国内法としては電波法，電信法抢よび航空法がある。

1） 国内航空通信 国内民間航空の運営のため必 要な航空機の発着報, 通過報その他の保安通信を行う ため, 千歳一三沢一仙台一東京一小牧一伊丹一岩国一 板付間に有線回線を専用儿，主にテレヌィプによる固 定通信を行つている。また気象, 飛行踼, 航空保安施
設などに関する航空情報の対空通信は，現在米軍によ り軍用機に対する通信の余㗇にきわめて不十分に行わ。 れているので, 航空機の安全かつ能率的な航空を確保 するため，短波による対空通信局の設置が望まれてい る。

2) 国際航空通信 東京国際空港に発着する国際民 間航空機に対し必要な保安通信を無線電信で東京国際 航空通信局から行つている。

この他, アラメカのコールドバア，アンカレージお よび釡山との間の北方回線, マニラ, 香港, 台北, 沖 繩などとの南方回線並びにグワム回線を以て，これら， の地点と固定通信を行つている。な打対空ヴォイス通 信は現在は周波からなる 通信路を以て太平洋全域の 航空機と通信,初つているが，同空域に抢ける航空交 通のふくそうによりその疎通に苦慮している現状であ る。

\section{XI. 航空交通管制}

これら諸施設の外に，航空交通管制というものが行 われなければ近代航空は成り立たない。これは戦時中 の航空の発達によりその必要が生じたものであり,こ れこそわれわれには全く経験のないことであつた。

一言にしてい元ば空の交通整理である。無限に広い はずの空域も，も早安全でなく昼夜の別なく高速で航 空機が飛びかう時代となつたので, これる秩序正しく 安全に飛ばすためには，地形，気象状態などを教慮す るのはもちろん前述の各種航空保安施設もできるだけ 完備して航空機が丁度汽車や電車のように, これをつ たつて飛ぶためのある币危持つた路を空の中に画く。 これを航空路といい国が設定して公示するのである。 この航空路上にある凡ゆる飛行機と情報を交換し, 必 要な指示た与えるのが航空交通管制区の仕事である。 このコントロールセンヌーは現在入間川と板付の 2 カ 所にあつて日本の国を東西に 2 分してコントロールし ている。また航空交通管制圈というのは飛行場と中心 としたある半湰荧持つたサークル内であってっこれは 飛行場の管制塔からコントロールする。わが国におけ る航空交通管制組織の管理は行政協定に基く日米合同 委員会で決定した「航空交通管制」に関する取極めに より，在日米軍が実施しているが，わが国が国際標準 に従つて同業務を提供できるようになつたときは，日 本側に移管されることになつている。現在この航空交 通管制組織が米軍によつて管理されていることは，必 然的にそのラジオ通信が米英語で行われる結果とな り，国内航空についても米英語を強要されることとな って,操縱にかけては腕が鳴るという昔の猛者連中き， 
管制に二対して全くの留であるため飛ぶないという現象 を来しているのである。自主運航態勢確立の為には， 早急にこれを日本側において矢施する必要が痛感され ている。シカゴ條約によれば管制は英棓および母国棓 を使用することになつているから，日本の航空機に対 しては日本語で応答ができるわけである。現在米軍が 行うている管制業務危全面的に引継ぐためには 455 名 の管制要員が要るので，その要員の養成にはすでに昭 和27年から力を入れて行つてい当が，今度は管制要員 の側に対米軍機や外国機に対して英語が話せることを 要求しなければならず，ての上航空機の運航に関し一 とおりの知識が必要であるから大変で, 英語ができ, 航空運航の経験がある者の湯合でも実地訓練を含め約 1 カ年の養成期間を要するといわれ，なかなか早急に はとの受入態勢がととのわず，再開㷋のわが航空の発 達に対し大きな障害となつていることはいなめない事 実である。

\section{XII. 航空従事者}

終戦当時航空機乘組員は，民閒のみで操縱士が 4,800 名, 航空士, 機関士および通信士を併せると12,000名 を数えたが，新航空法による資格を獲得したものは操 縱士で約 700 名, 航空士, 通信士夫々約 300 名, 整㣁 土約 200 名並びに機関士約 30 名である。操縦士につい ては 4 つの種類があつて, 定期航空運送事業に従事で きる資格のある，いわゆる定期運送用操緃士はこの中 122 名であり，乙かもその半数は外国人であるために 日航機のパイロッ下起亲だ全部日本人に切替えること ができないのである。何しろ教育に当る教官が先ずい ないという有様であつたので, 政府としても昭和27年 度加ら乘員養成補助金觉交付し, て, 乘員在米国に派遣, 再教育を受けさせるなど力を入れてきたが，さらに眧 和29年度からは宫崎に航空大学校を設置して, その養 成に当っているが，まだ所有機が少く規模も小さくて 十分な人数を教育できない現状である。

XIII. 結 び
以上民間航空の当面する問題の数々をあげたが，こ れらを平行的に解決し世界的なレベルまで持ち上げる ことはいかに難事業であり，多額の経費と相当の時間 灰要することかお察し願えたと思う。緊縮財政の現段 階においては非常に苦しいことであるが，今後朝鮮， 台湾をはじめ東南アジア方面や中共地域之の交通が頻 繁になると，一段と重要性を加えることは明らかでゆ るがせにできない問題である。日航が次の国際航空使 用機として予定したコヌットは御承知のような大さて つを来しているのでその計画は再検討を要しこれに 代るものとして同じくイギリスのブリストル・ブリタ ニヤ,アメリカのダグラス DC-7C, DC-8, ロッキード 1249B 抢よびボーイング 707 などがあげられている。 DC-7C はピストンエンジン，ボーイングと DC-8 と はターボジェットェンジンその他はターボプロップエ ンジン装備であつて, 将来の国際線の花形がターボプ ロップになるか，いきなりコメッ下を含むこれらジェ ットの時代になるかは目下非常に興味を持つてみられ ている間題である。まだ決定の段階ではないが，いず れをとつても 1 機大体 400 万弗前後と予定されている ので，余程しつかりした見透しをつけ慎重に研究する 必要がある。国内線についても，そういつまでもDC一 4 の時代が続くとは思えず, 朝鮮, 台湾など近隣諸国 を加光て，ヴィッカース，ヴァイカウントか，コン ベア 340 、に代元られる時期がくるのではあるまいか。 漸く先般航空活動の再開を許された西ドイツに抢いて は，ルフトハンザ航空会社が，このヴァイカウントと コンぶアを用いて近く定期航空を開始すると伝元られ ている。一方日航以外の各事業者が叔らつているのは 国内ローカル定期じあつて北海道々内線, 東京一新潟 一小松一大阪の北陸線, 大阪一米子線, '四国抢よび九 州の島内循環線などが主なものであるが，そのために は国内航空路の整備拡充と航空艾通管制の自主的運営 と在必要とすることはすでに述べたと抢りで，航空局 としてもこの線に沿つて全力觉傾けている次第である。

\title{
The Present Status and Future of Civil Aviation in Japan
}

\author{
by Shinichi Ōsawa
}

(Bureau of Aviation, Department of Transportation)

SYNOPSIS: - It has heen only three years since the civil aviation in Japan started again after many years blank, and so it is far behind of foreign countries.

It is foreseen that the communication with Korea, Formosa, Red China and other East-Southern Asia will be busy in future and that the civil aviation in Japan becomes more and more important.

Japanese civil aviation, accordingly, must be raised up to the level in the world as soon as possible after the settlement of many problems with which it is now faced. 